\title{
PENERAPAN LOCAL BINARY PATTERN UNTUK MENGUKUR TINGKAT KEPUASAN PENGUNJUNG SECARA OTOMATIS
}

\author{
Elke Cahya Putri ${ }^{1}$, Bayu Priyambadha ${ }^{2}$, Fajar Pradana ${ }^{3}$ \\ ${ }^{1,2,3}$ Fakultas Ilmu Komputer, Universitas Brawijaya \\ Email: 1'elkecahya @student.ub.ac.id, ${ }^{2}$ bayu_priyambadha@ub.ac.id, ${ }^{3}$ fajar.p@ub.ac.id
}

(Naskah masuk: 26 November 2018, diterima untuk diterbitkan: 27 Mei 2019)

\begin{abstract}
Abstrak
Pusat Konservasi Tumbuhan Kebun Raya-LIPI merupakan organisasi pemerintah yang berfokus pada bidang konservasi tumbuhan yang sekaligus berperan sebagai pihak pengelola kebun raya Bogor. Pihak pengelola membutuhkan masukkan atau testimoni pengunjung sebagai bahan evaluasi pelayanan yang diberikan untuk pengunjung. Pada pelaksanaannya, selama ini pengunjung memberikan masukkannya pada laman fanpage facebook kebun raya Bogor. Cara ini dianggap kurang akurat untuk merepresentasikakn tingkat kepuasan pengunjung hanya berdasarkan tulisan yang di publikasikan. Dari permasalahan tersebut maka dikembangkan salah satu fitur pada sistem Layanan Online Kebun Raya Bogor untuk mempermudah pengunjung Kebun Raya Bogor memberikan masukkan atau testimoni kepada pihak pengelola. Testimoni yang di unggah tidak hanya dalam bentuk tulisan tetapi juga dalam format gambar yang terdapat objek manusia, gambar yang di unggah nantinya akan di deteksi dengan menggunakan Local Binary Pattern (LBP) untuk mendapatkan hasil klasifikasi dari ekspresi yang ditunjukkan. Hasil pendeteksian gambar dapat digunakan sebagai analisis tingkat kepuasan pengunjung terhadap pelayanan yang diberikan oleh pihak pengelola dari jumlah ekpresi pada satu lokasi objek wisata. Dari hasil penelitian yang dilakukan, didapatkan hasil akurasi pendeteksian gambar sebesar 0.884 terhadap pengklasifikasian ekspresi wajah yang di dapatkan.
\end{abstract}

Kata kunci: Local Binary Pattern, Kebun Raya Bogor

\section{THE APPLICATION OF LOCAL BINARY PATTERN FOR MEASURING THE LEVELS OF VISITOR'S SATISFACTION AUTOMATICALLY S}

\begin{abstract}
Plant Conservation Center Botanical Garden-LIPI is a government organization engaged in the conservation of plants and have a role as Kebun Raya Bogor organizer. The organizer requires visitor input or testimonial as a visitor service evaluation material. In its implementation, visitors gave their testimonial on the Kebun Raya Bogor Facebook fanpage. This method is considered less accurate to represent the level of visitor satisfaction based solely on the published texts. From that issue emerged an initiative to develop a feature on the Online Service system of Kebun Raya Bogor to facilitate Kebun Raya Bogor visitors to give testimonials to the organizer. Testimonials that are sent not only in the form of texts but also in the image format that contains the human object, the uploaded image will be detected by using the Local Binary Pattern (LBP) to get the result of the expression it captures. The results of image detection can be used to analyzed how the level of visitor satisfaction with the services provided by the organizer in a tourist attraction location. From this study, the result obtained an accurate image detection of 0.884 by using LBP for the classification of captured facial expression
\end{abstract}

Keywords: Local Binary Pattern, Bogor Botanical Garden

\section{PENDAHULUAN}

Pusat Konservasi Tumbuhan Kebun RayaLIPI (PKT Kebun Raya-LIPI) merupakan salah satu organisasi milik pemerintah yang berfokus pada bidang konservasi tumbuhan yang ada di Indonesia. PKT Kebun Raya-LIPI mengelola atau memberikan pengawasan terhadap seluruh kebun raya yang ada di Indonesia salah satunya yang ditangani secara langsung yaitu kebun raya Bogor. Sebagai pihak pengelola kebun raya Bogor selalu ingin memberika fasilitas dan pelayanan yang terbaik untuk pengunjung kebun raya Bogor.

Salah satu cara yang dilakukan untuk meningkatkan pelayanan dan fasilitas yaitu dengan 
melakukan evaluasi dengan kinerja yang telah dilaksanakan selama ini dengan membandingkan tingkat kepuasan pengunjung kebun raya Bogor. Pemberian masukkan dari pengunjung kebun raya Bogor sangat bermanfaat sebagai bahan evaluasi kinerja demi perbaikan pelayanan yang diberikan. Selama ini salah satu cara yang dilakukan pengunjung untuk memberikan masukkan atau testimoni kepada pihak kebun raya Bogor yaitu melalui laman fanpage facebook kebun raya Bogor. Pada laman fanpage facebook kebun raya Bogor tak sedikit pengunjung yang memberikan pengalamannya atau masukkan hanya berupa katakata tanpa ada bukti pendukung pendapatnya, contohnya tanpa diberikan foto pendukung. Hal ini menjadi suatu masalah bagi pengunjung lainnya yang menanyakan akan kebenaran dari statement atau pendapat yang di tuliskan sesuai dengan kenyataannya atau tidak.

Berdasarkan hasil penelitian yang berkaitan dengan pengambilan keputusan dalam menentukan suatu perjalanan atau lokasi wisata menunjukkan bahwa, para konsumen menggunakan berbagai jenis sumber informasi online pada proses perjalanannya, baik pada saat sebelum melakukan perjalanan, selama perjalanan, maupun setelah perjalanan selesai (Choi et al., 2007; Seabra, Abrantes, \& Lages, 2007). Dari penelitian itu menunjukkan bahwa peran masukkan atau testimoni pengunjung kebun raya Bogor pada laman fanpage facebook kebun raya Bogor sangatlah penting bagi pihak pengelola. Selain dari masukkan atau testimoni tersebut dapat dijadikan bahan evaluasi kinerja, dapat dijadikan untuk bahan promosi kebun raya Bogor sebagai lokasi wisata yang memiliki rating tinggi berdasarkan tingkat kepuasan pengunjung.

Untuk menghitung tingkat kepuasan pengunjung kebun raya Bogor dapat dihitung dari testimoni foto yang diberikan. Dimana dari foto tesebut akan dilakukan pendeteksian ekspresi yang tampak pada saat foto itu diambil di suatu lokasi objek wisata di kebun raya Bogor. Hasil dari penelitian sebelumnya, Local Binary Pattern (LBP) dapat diterapkan untuk mendeteksi suatu ekspresi mikro dari seseorang yang di klasifikasi menjadi 5 ekspresi mikro, yaitu happiness, surprise, sadness, disgust dan others (Amynarto, N., Sari, Y., \& Wihandika, R., 2018). Dengan memiliki hasil akurasi sebesar $70,21 \%$ pada penelitian tersebut, dapat disimpulkan bahwa LBP dianggap mampu dit implementasikan untuk melakukan suatu pendeteksian dari sebuah foto atau gambar guna mengetahui ekspresi mikro dari seseorang. LBP dapat berfungsi secara optimal untuk mendeskripsikan suatu tekstur karena memiliki daya pembeda yang sangat akurat dan LBP juga memiliki sifat toleransi terhadap perubahan gray-scale secara monotonic (Turiyanto, Purwanto, \& Dikairono, 2014). Penelitian lainnya di dapatkan bahwa LBP dapat di implementasikan untuk mendeteksi suatu pola dari huruf hiragana dengan akurasi sebesar $81,1 \%$ yang dianggap cukup baik dalam melakukan pengenalan pola huruf hiragama yang dilakukan dengan 460 data sample uji (Amat, R., Sari, J,Y., Ningrum, I,P., 2017).

Telah diketahui bahwa LBP dapat diterapkan untuk melakukan suatu pendeteksian dari sebuah foto atau gambar dengan cara membandingkan nilai ketetanggan dengan nilai tengahnya, sehingga dapat mendapatkan hasil yang optimal. Berdasarkan dari hasil penelitian yang dilakukan sebelumnya, LBP dianggap mampu dapat diterapkan untuk melakukan pendeteksian tingkat kepuasan pengunjung kebun raya Bogor dengan hasil akhir sebuah grafik tingkat kepuasan pengunjung terhadap pelayanan yang telah diberikan selama ini oleh pihak pengelola. Pada penelitian ini akan dibagi menjadi 7 bagian, yaitu pada bagian pertama membahas terkait latar belakang permasalahan dari penelitian ini yang ada di kebun raya Bogor dalam menentukan tingkat kepuasan pengunjung sebagai bahan evaluasi kinerja. Pada bagian kedua akan menjelaskan terkait dengan algoritme LBP yang akan di implementasikan dalam penelitian ini. Pada bagian ketiga akan menjelaskan terkait dengan metode pencarian jarak ketetanggan atau sering disebut dengan $K$-Nearest Neighbour (KNN) dari hasil nilai LBP dengan data latih agar di dapatkan hasil satu ekspresi yang menggambarkan foto atau gambar yang diunggah pengunjung kebun raya Bogor. Pada bagian ke empat akan menjelaskan terkait dengan alur penelitian yang diterapkan, dari mulai tahap awal mengumpulkan data, melakukan klasifikasi dari hasil deteksi LBP sampai dengan menyimpulkan akurasi perhitungan dengan menentukan nilai dari koefisien kappa. Pada bagian ke lima yaitu studi kasus dan ke enam yaitu hasil pembahasan. Dimana pada bagian lima dan enam akan membahas terkait dengan perhitungan penyelesain masalah dan hasil analisis akhir dari penelitian ini. Pada bagian terakhir yaitu bagian itu ajan membahas terkait dengan kesimpulan yang dapat diambil dari penelitian ini.

\section{LOCAL BINARY PATTERN}

LBP merupakan metode analisis tekstur yang menggunakan model statistika dan tersturtur yang diperkenalkan pertama kali oleh Ojela et al. LBP merupakan sebuah ukuran dari tekstur gray-scale yang invarian. Dimana hasil yang di dapatkan hampir tidak dipengaruhi oleh seberapa besar perbedaan pencahayaan yang berbeda (Turiyanto, Purwanto, \& Dikairono, 2014). LBP menggunakan perbandingan nilai keabuan dari tetangganya, dimana LBP menggunakan 8 piksel ketetanggan $\left(g_{p}\right)$ dari sebuah piksel yang berada di tengah $\left(g_{c}\right)$. Pada persamaan 1 dilakukan proses perhitungan pengurangan nilai piksel ketetanggan dengan piksel tengahnya. Kemudian hasil dari pengurangan akan dilakukan threshold dengan menggunakan 
Persamaan 2, apabila nilai yang dihasilkan $<0$, maka akan diberi nilai 0 dan apabila nilai yang dihasilkan bernilai $\geq 0$ maka akan diberi nilai 1 .

$$
\begin{aligned}
& L B P_{b, R}\left(x_{c}, y_{c}\right)=\sum_{b=0}^{b-1} s\left(g_{p}-g_{c}\right) 2^{b} \\
& s(x)=\left\{\begin{array}{l}
1, x \geq 0 \\
0 . x<0
\end{array}\right.
\end{aligned}
$$

Keterangan :

$$
\begin{array}{ll}
\mathrm{P} & \text { : jumlah piksel tetangga } \\
\mathrm{R} & \text { : nilai radius } \\
g_{c} & \text { : nilai piksel } x, y \\
g_{p} & \text { : nilai piksel tetangga }
\end{array}
$$

Setelah di dapatkan nilai binernya, nilai biner piksel ketetanggaan akan disusun berdasarkan berlawanan dari arah jarum jam dan 8 bit biner tesebut akan di konversi ke dalam nilai desimalnya untuk menggantukan nilai piksel yang berada di tengah $\left(g_{c}\right)$. Pada Gambar 1 merupakan visualisasi dari perhitungan LBP.

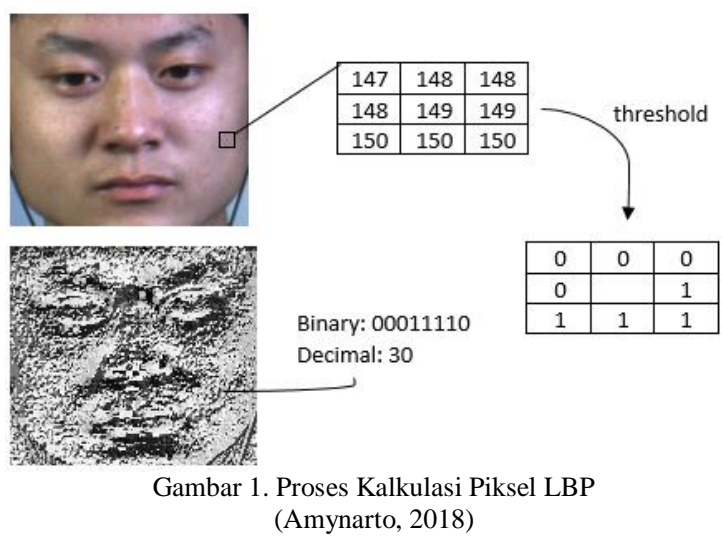

\section{K-NEAREST NEIGHBOUR}

KNN merupakan salah satu metode yang digunakan untuk pengklasifikasian. Prinsip kerja dari KNN adalah dengan cara mencari jarak terdekat antara data yang akan di evaluasi dengan $\mathrm{K}$ tetangga (neighbor) terdekatnya. Salah satu metode dalam menghitung ketetanggan yaitu Manhattan Distance. Dimana untuk melakukan pendeteksian tingkat kemiripan suatu gambar, dapat dilakukan dengan menghitung nilai absolut dari pengurangan dua atau lebih vektor. Perhitungan ini akan menggunakan jarak paling minimum untuk dapat menentukan suatu kemiripannya dengan menggunakan rumus pada Persamaan 3.

$$
d(x, y)=\sum_{r=1}^{n}\left\|x_{i}-y_{i}\right\|
$$

Keterangan :

$d(x, y):$ Manhattan distance dari $x_{i}$ dan $y_{i}$

$x_{i} \quad$ : data pada $x$ ke- $i$ yang akan di lakukan perhitungan. $y_{i} \quad$ : data pada $y$ ke- $i$ yang akan di lakukan perhitungan.

\section{METODOLOGI}

Terdapat beberapa tahapan yang akan dilakukan pada penelitian ini yang dapat dilihat pada Gambar 2 diagram alir penelitian.

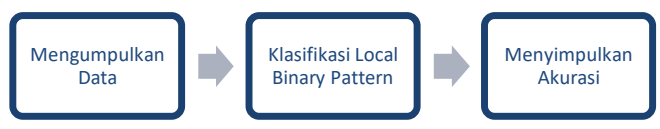

Gambar 2. Diagram Alir Penelitian

\subsection{Mengumpulkan Data}

Data yang digunakan sebagai data uji dalam penelitian ini merupakan foto pengunjung kebun raya Bogor dengan ekstensi file selain gif sebanyak 50 foto. Selain itu pada penelitian ini juga memerlukannya adanya data latih dengan menggunakan database CASME II. Pada penelitian sebelumnya yang berjudul CASME II: An Improved Spontaneous Micro-Expression Basis data and the Baseline Evaluation di dapatkan beberapa ekspresi yang nantinya digunakan dalam penelitian ini. Pada penelitian ini akan menggunakan 5 kategori ekspresi, yaitu happiness, surprise, sadness, disgust dan other. Dimana other merupakan ekspresi yang tampak selain kategori happiness, surprise, sadness dan disgust. Pada penelitian ini juga meminta seorang pakar untuk memberikan sebuah label pada foto pengunjung kebun raya Bogor yang nantinya, hasil dari pelabelan yang dilakukan oleh pakar akan dicocokan dengan hasil dari pendeteksian sistem. Jumlah foto yang dilakukan pemberian label oleh pakar sebanyak 50 foto, diamana foto yang digunakan sama seperti foto yang digunakan untuk pengujian sistem.

\subsection{Klasifikasi Local Binary Pattern}

Untuk melakukan klasifikasi dari hasil pendeteksian menggunakan LBP dilakukan dengan beberapa tahapan yang dapat dilihat pada gambaran umum sistem pada Gambar 3.

Pada penelitian ini untuk mendapatkan hasil dari pendeteksian menggunakan LBP dilakukan beberapa proses yaitu sebagai berikut :

1. Memasukkan Gambar

2. Konversi RGB ke Gray-scale

Konversi gambar dari RGB ke gray-scale berfungsi untuk mengubah gambar menjadi keabuan. Langkah pertama yaitu melakukan inisialisasi terhadap nilai $\mathrm{x}$ dan $\mathrm{y}$. Kemudian mengambil nilai warna merah, hijau dan biru pada gambar yang di inputkan. Dari nilai merah, hijau dan biru tersebut dijumlahkan dan 
kemudian dibagi dengan 3 menghasilkan nilai gray-scale. Dimana nilai gray-scale ini yang digunakan untuk menggantikan nilai RGB pada piksel baru $(\mathrm{x}, \mathrm{y})$. Langkah berikutnya yaitu dilakukannya penambahan nilai y untuk memproses piksel berikutnya. Setelah nilai y $<=$ tinggi gambar maka dilakukan penambahan nilai x. Setelah semua piksel telah dihitung, maka akan menghasilkan gambar gray-scale.

3. Cropping

Tahapan cropping berfungsi untuk mengambil objek wajah yang akan digunakan. Pada tahapan cropping ini memanfaatkan fitur HaarCascade yang disediakan oleh library OpenCV.

4. Ekstraksi LBP

Untuk melakukan ekstraksi LBP langkah pertama yang dilakukan yaitu melakukan inisialisasi terhadap nilai $(\mathrm{x}, \mathrm{y})$ dan membuat variable penampung yang nantinya digunakan untuk menyimpan nilai tengah piksel. Langkah berikutnya yaitu melakukan perhitungan dengan kondisi apabila nilai $\mathrm{x}>0$ dan $\mathrm{x}<$ lebar gambar dikurangi 1 dan $\mathrm{y}>0$ dan $\mathrm{y}<$ tinggi gambar dikurangi 1, ini dilakukan untuk menentukan batas ketetanggan. Apabila kondisi tersebut terpenuhi maka akan mengambil nilai tengah dan nilai ketetanggaannya. Selanjutnya membandingkan nilai tengah dengan ketetanggannya menggunakan Persamaan 1 dan Persamaan 2.

5. Hitung Jarak

Untuk menentukan jarak, pada penelitian ini menerapkan perhitungan Manhattan Distance pada Persamaan 3.

6. Hasil

Untuk menentukan hasil klasifikasi dari pendeteksian sistem dapat dilihat pada diagram alir klasifikasi pada Gambar 4.

\subsection{Menyimpulkan Akurasi}

Setelah mendapatkan hasil deteksi klasifikasi ekspresi dari sistem, maka akan di cocokan dengan prediksi dari pakar yang akan di representasikan dengan menggunakan tabel kebenaran seperti pada Tabel 1.

Tabel 1. Tabel kebenaran

Sistem

\begin{tabular}{c|c}
\hline Pakar & TP \\
\cline { 2 - 2 } & \\
\hline FP & TN \\
& \\
\hline
\end{tabular}

Keterangan :

a. TP (True Positif)

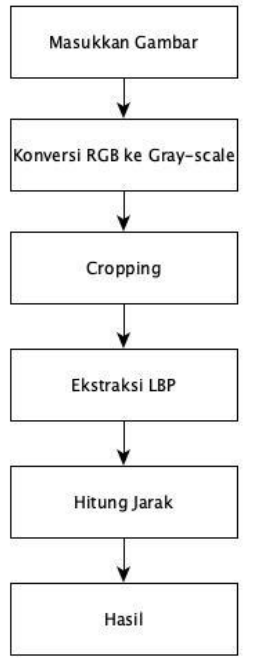

Gambar 3. Gambaran Umum Sistem

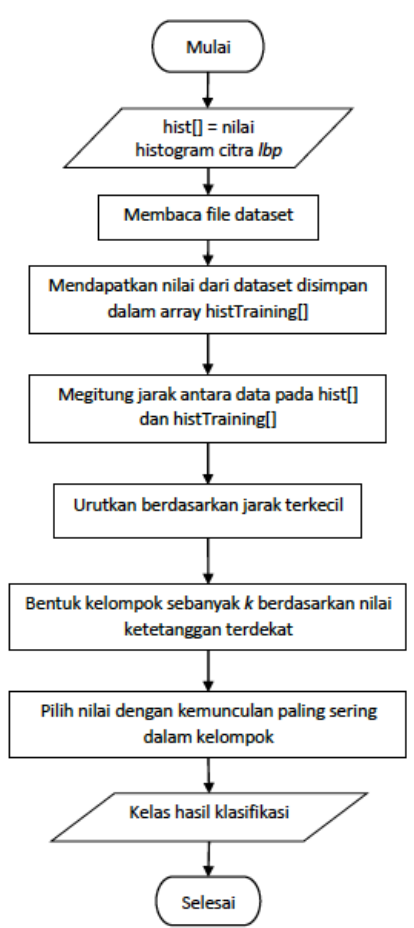

Gambar 4. Diagram Alir Klasifikasi

Apabila pakar dan sistem menghasilkan hasil deteksi yang positif.

- Pakar "happiness" sistem memutuskan "happiness".

- Pakar "surprise" sistem memutuskan "surprise".

- Pakar "sadness" sistem memutuskan "sadness".

- Pakar "disgust" sistem memutuskan "disgust". 
- Pakar "others" sistem memutuskan "others".

b. TN (True Negative)

Apabila pakar dan sistem menghasilkan hasil yang negative.

- Pakar tidak "happiness" sistem memutuskan tidak "happiness".

- Pakar tidak "surprise" sistem memutuskan tidak "surprise".

- Pakar tidak "sadness" sistem memutuskan tidak "sadness".

- Pakar tidak "disgust" sistem memutuskan tidak "disgust".

- Pakar tidak "others" sistem memutuskan tidak "others".

c. FP (False Positif)

Apabila pakar negative, tetapi sistem memutuskan positif.

- Pakar tidak "happiness" sistem memutuskan "happiness".

- Pakar tidak "surprise" sistem memutuskan "surprise".

- Pakar tidak "sadness" sistem memutuskan "sadness".

- Pakar tidak “disgust” sistem memutuskan "disgust".

- Pakar tidak "others" sistem memutuskan "others".

d. FN (False Negative)

Apabila pakar positif, tetapi sistem memutuskan negative.

- Pakar "happiness" sistem memutuskan tidak "happiness".

- Pakar "surprise" sistem memutuskan tidak "surprise".

- Pakar "sadness" sistem memutuskan tidak "sadness".

- Pakar "disgust" sistem memutuskan tidak "disgust".

- Pakar "others" sistem memutuskan tidak "others".

Validitas sistem dapat dihitung dengan menggunakan dari nilai $\mathrm{TP}, \mathrm{FN}, \mathrm{FP}$, dan $\mathrm{TN}$ dengan rumus sebagai berikut :

$$
\text { Koefisien }=\frac{T P+T N}{T P+T N+F P+F N}
$$

Keterangan :

TP : nilai dari True Positif

TN : nilai dari True Negative

FP : nilai dari False Positive

FN : nilai dari False Negative
Setelah mendapatkan nilai dari koefisien kappa dapat di interpretasikan sesuai dengan range yang dikemukakan oleh Landis dan Koch (1977) pada Tabel 2.

Tabel 2. Tabel Interpretasi

\begin{tabular}{c|c}
\hline Index & Strength of Aggrement \\
\hline$<0.00$ & Poor \\
\hline $0.00-0.20$ & Slight \\
\hline $0.21-0.40$ & Fair \\
\hline $0.41-0.60$ & Moderate \\
\hline $0.61-0.80$ & Substantial \\
\hline $0.81-1.00$ & Almost Perfect \\
\hline
\end{tabular}

\section{STUDI KASUS}

Studi kasus dalam penelitian ini menggunakan database dari CASME II terdapat 256 gambar yang sudah di klasifikasikan atau diberi label sesuai dengan ekspresinya. Klasifikasi ekspresi yang akan digunakan yaitu happiness, surprise, sadness, disgust dan others. Kemudian akan dibandingkan data dari hasil deteksi sistem dengan prediksi pakar dapat dilihat dari Tabel 3 beberapa sample data uji yang dilakukan.

Tabel 3. Sampel data uji

\begin{tabular}{c|c|c}
\hline Data Ke-i & Pakar & Sistem \\
\hline 1 & Happiness & Happiness \\
\hline 2 & Happiness & Happiness \\
\hline 3 & Surprise & Surprise \\
\hline 4 & Surprise & Surprise \\
\hline 5 & Surprise & Surprise \\
\hline 6 & Surprise & Surprise \\
\hline 7 & Surprise & Surprise \\
\hline 8 & Surprise & Surprise \\
\hline 9 & Surprise & Surprise \\
\hline 10 & Others (Anger) & Surprise \\
\hline
\end{tabular}

Pada proses pelabelan oleh pakar, pakar mengkategorikan ekspresi seseorang berdasarkan kriteria tertentu, yaitu sebagai berikut :

1. Kategori Happiness

Dapat dilihat pada bagian otot pipi yang bergerak naik dan juga kedua sisinya dengan tepi bibir membentuk senyuman.

2. Kategori Surprise

Dapat dilihat dari kedua alis mata naik, disertai mata terbuka lebar, serta mulut yang refleks terbuka (menganga namun tak terlalu lebar).

3. Kategori Sadness

Dapat dilihat dari bagian mata nampak tidak focus (konsentrasi cenderung menerawang), dengan bagian bibir ditarik ke arah bawah, dan juga kelopak mata atas mengarah ke bawah.

4. Kategori Disgust

Dapat dilihat dari area batang hidung yang berkerut dan bibir atas naik., dahi berkerut dengan alis mengarah ke dalam 
Menurut pakar, untuk setiap individu memiliki presepsi melihat ekspresi wajah yang ditampilkan berbeda-beda, hal ini dikarenakan persepsi terhadap stimulus yang diterima setiap orang berbeda karena pengalaman, kebutuhan, motif, keinginan, ketakutan, harapan, sikap, prasangka, dan sebagainya. yang berbeda pada tiap individu. Berdasarkan dari hasil uji yang di dapatkan, maka dapat di konversi ke dalam table yaitu seperti terlihat pada Tabel 4.

Tabel 4. Truth Table

\begin{tabular}{cccccc}
\hline & Happiness & Surprise & Sadness & Disgust & $\begin{array}{c}\text { Oth } \\
\text { er }\end{array}$ \\
\hline Happiness & 7 & 1 & 0 & 2 & 1 \\
Surprise & 0 & 16 & 0 & 0 & 0 \\
Sadness & 0 & 0 & 2 & 0 & 0 \\
Disgust & 0 & 1 & 0 & 4 & 0 \\
Other & 3 & 0 & 0 & 2 & 0 \\
\hline
\end{tabular}

$\mathrm{TP}=29$

$\mathrm{TN}=116$

$\mathrm{FP}=9$

$\mathrm{FN}=10$

Langkah berikutnya yaitu menghitung koefisien kappa dengan menggunakan Persamaan 4.

$$
\text { Koefisien }=\frac{29+116}{29+116+9+10}=0.884
$$

\section{HASIL PEMBAHASAN}

Berdasarkan hasil dari perhitungan koefisien kappa dapat diinterpretasikan bahwa tingkat kesepakatan antara hasil pendeteksian sistem dengan hasil pendeteksian yang dilakukan pakar termasuk ke dalam kategori almost perfect dengan nilai koefisien 0.884. Namun pada saat melakukan uji coba, tidak semua hasil pendeteksian dari sistem dan pakar memiliki hasil yang sama, hal ini dikarenakan mungkin pakar salah dalam melakukan analisis gerakan alis, tarikan dahi, gerakan sudut bibir, gerakan sudut mata, pencahayaan dan lain sebagainya. Dengan hasil nilai akurasi yang termasuk ke dalam kategori almost perfect, LBP dapat di implementasikan guna dapat merepresentasikan ekspresi tingkat kepuasan pengunjung kebun raya Bogor.

\section{KESIMPULAN}

Kesimpulan yang dapat diambil dari adanya penelitian ini yaitu :

1. Mengimplementasikan LBP sebagai salah satu metode yang dianggap mampu menyelesaikan persmasalahan untuk melakukan otomatisasi mendeteksi tingkat kepuasan pengunjung.

2. Perbedaan hasil deteksi dari LBP dengan pakar disebabkan adanya perbedaan gerakan alis, tarikan dahi, gerakan sudut bibir, gerakan garis sudut kepala, gerakan otot pipi dan lain sebagainya yang dapat memberikan hasil yang berbeda.

3. Hasil akurasi juga dipengaruhi oleh pose dari objek, fokus dari titik mata, gerakan bibir, kelopak mata dan beberapa faktor lainnya yang menyebabkan antar individu dapat memiliki ekspresi yang berbeda

4. Berdasarkan hasil analisis di peroleh nilai dari koefisien kappa sebesar 0.884 dapat diinterpretasikan bahwa tingkat kesepakatan antara hasil pendeteksian sistem dengan hasil pendeteksian yang dilakukan pakar termasuk ke dalam kategori almost perfect.

\section{DAFTAR PUSTAKA}

AMAT, R., SARI, J,Y., NINGRUM, I,P., 2017. Implementasi Metode Local Binary Patterns Untuk Pengenalan Pola Huruf Hiragana Dan Katakana Pada Smarthphone

ANDELIN, E. I., \& RUSU, A. S. 2015. Investigation of facial microexpressions of emotions in psychopathy - a case study of an individual in detention. Procedia-Social and Behavioral Sciences 209, 46-52.

E. WAHYUDI, H. KUSUMA, \& WIRAWAN. 2011. Perbandingan Unjuk Kerja Pengenalan Wajah Berbasis Fitur Local Binary Pattern dengan Algoritma PCA dan Chi Square.

PIETIKAINEN, M., HADID, A., ZHAO, G., \& AHONEN, T. 2011. Computer Vision Using Local Binary Pattern. 13-47.

REPUBLIK INDONESIA. 2011. Peraturan Presiden Nomor 93 Tahun 2011 tentang Kebun Raya (Lembaran Negara Republik Indonesia Tahun 2011 Nomor 143).

SEABRA, C., ABRANTES, J. \& LAGES, L. 2007. The impact of external information sources in expectations formation and future use of media. Tourism Management. 28(6): 15411554.

TURIYANTO, M. D., PURWANTO, D., \& DIKAIRONO, R. 2014. Penerapan Teknik Pengenalan Wajah Berbasis Fitur Local Binary Pattern pada Robot Pengantar Makanan. 1-6.

YAN, W.-J., Li, X., WANG, S.-J., ZHAO, G., LIU, Y.-J., CHEN, Y.-H., \& FU, X. 2014. CASME II: An Improved Spontaneous Micro-Expression Database and the Baseline Evaluation. 1-9. 